tainers of amber glass which does not transmit any radiation below 370 or $380 \mathrm{~m} \mu$. This should avoid photochemical destruction of apparent vitamin $\mathrm{C}$ in the form of reductone, reductic acid or dihydroxymaleic acid, also of true vitamin $\mathrm{C}$, which Mohler and Lohr ${ }^{3}$ found to have a subsidiary maximum at about $350 \mathrm{~m} \mu$ in potassium cyanide solution, equivalent to about $340 \mathrm{~m} \mu$ in water. There is evidence that the vitamin $\mathrm{C}$ in fruit syrup stored in white glass bottles under normal conditions may be destroyed by sunlight.

While our results have not provided any evidence for the production of apparent vitamin C by the action of sunlight on processed foods, the position may be different in regard to natural foods such as fruits which are subjected to prolonged solar radiation during ripening and contain enzymes and pig. ments which may modify the conditions.

Ovaltine Research Laboratories,

Frank Wokes.

King's Langley, Herts. July 28.

1 Griffiths, J. G. A., Nature, 152, 163 (1943).

${ }^{2}$ Euler, H. v., and Martius, C., Annalen, 505, 73 (1933).

3 Mohler, H., and Lohr, H., Helv. Chim. Acta, 21, 485 (1938).

\section{Vitamin C and Carbohydrate Metabolism}

IT has been shown previously ${ }^{1,2}$ that deficiency of vitamin $\mathrm{C}$ in guinea pigs leads to a change in the carbohydrate metabolism as judged by (1) the glycosuria, (2) the diabetic type of the glucose tolerance curve, and (3) the depletion of the glycogen content of the liver. It has also been shown that the normal metabolism of carbohydrate is restored after the administration of vitamin $\mathrm{C}$. From the above evidence, it has been suggested that the action of vitamin $\mathrm{C}$ is similar to that of insulin.

In the present investigation the insulin content of the pancreas of normal and scorbutic guinea pigs has been studied. Normal healthy male guinea pigs (200-300 gm. wt.) were selected. Some of the animals were fed on a scorbutic diet consisting of crushed barley, 64 parts; crushed gram, 20 parts ; casein, 12 parts ; common salt, 1 part; calcium carbonate 3 parts ; cod liver oil, 2 c.c. ; for a period of 24-28 days. until the animals developed scurvy. Other animals were fed on an ordinary diet consisting of green grass, germinated gram, outer green leaves of cabbage, etc., for two weeks.

Prior to the removal of the pancreas the animals were fasted overnight. The pancreases of 5-7 animals

TABLE 1. NORMal gUINeA PIGS.

\begin{tabular}{|c|c|c|c|c|}
\hline $\begin{array}{c}\text { Ali- } \\
\text { quot } \\
\text { No. }\end{array}$ & $\begin{array}{c}\text { Number } \\
\text { of } \\
\text { guinea } \\
\text { pigs }\end{array}$ & $\begin{array}{c}\text { Weight } \\
\text { of pan- } \\
\text { creatic } \\
\text { tissue }\end{array}$ & $\begin{array}{c}\text { Percentage blood- } \\
\text { sugar reduction } \\
\text { by the extract } \\
\text { from 1 } 1 \text { gm. of } \\
\text { pancreas }\end{array}$ & $\begin{array}{c}\text { Insulin content } \\
\text { per gm. of } \\
\text { pancreas }\end{array}$ \\
\hline 1 & 6 & $6 \cdot 0 \mathrm{gm}$. & $16 \cdot 0$ & $>1$ unit \\
2 & 7 & $7 \cdot 0$ & $30 \cdot 5$ & $1.2, "$, \\
3 & 6 & $6 \cdot 0$ & $15 \cdot 6$ & $>1$ \\
4 & 7 & $5 \cdot 6$ & $13 \cdot 0$ & $>1$ \\
\hline
\end{tabular}

Table 2. Scorbutic guinea pigs.

\begin{tabular}{|c|c|c|c|c|}
\hline $\begin{array}{c}\text { Ali- } \\
\text { quot }\end{array}$ & $\begin{array}{c}\text { Number } \\
\text { of } \\
\text { guinea. } \\
\text { pigs }\end{array}$ & $\begin{array}{c}\text { Days on } \\
\text { scorbu- } \\
\text { tic diet }\end{array}$ & $\begin{array}{c}\text { Weight of pan- } \\
\text { creatic tis sue }\end{array}$ & $\begin{array}{c}\text { Percentage blood- } \\
\text { sugar reduction } \\
\text { with extract from } \\
1 \text { gm. of pancreas }\end{array}$ \\
\hline 1 & 5 & 26 & $5.5 \mathrm{gm}$. & 0 \\
2 & 6 & 24 & $6 \cdot 0$ & 0 \\
3 & 5 & 24 & 5.0 & 0 \\
4 & 6 & 28 & 6.0 & 0 \\
\hline
\end{tabular}

were pooled and extracted for insulin according to the method of Best et al. ${ }^{3}$. The crude insulin precipitate obtained was dissolved in normal saline of $p \mathrm{H} 2.5$ so that 0.5 c.c. of the solution represented $1 \mathrm{gm}$. of pancreas. The potency of the solution was tested by studying the hypoglycæmic reaction in rabbits as described by Marks ${ }^{4}$. The results are shown in Tables 1 and 2. They definitely indicate that the insulin content of the pancreas is markedly diminished in scurvy.

International standard insulin was obtained through the courtesy of Dr. B. Mukerji, director of the Standardization Laboratory, Government of India. Thanks are due to Dr. B. M. Das Gupta, director of the School of Tropical Medicine, for his interest in the present investigation. SACHCHIDANANDA BANERJEE.

School of Tropical Medicine,

Chittaranjan Avenus,

Calcutta. June 14.

${ }^{1}$ Banerjee, S., Indian $J$. Med. Res., in the press.

${ }^{2}$ Banerjee, S., Indian Med. Gaz., in the press.

s Best, C. H., Haist, R. E., and Ridout, J. H., J. Physiol., 97, 137 (1939).

- Marks, C. H., Quarterly Bulletin of the Health Organization, League of Nations, Geneva, Special Number, November 1936.

\section{Short Wave-length Limit of the Continuous X-Ray Spectrum and Determinations of $h / e$}

As is known, there exists a discrepancy between earlier determinations of $h / e$ obtained from the short. wave-length limit of the continuous X-ray spectrum and the value of h/e calculated from Bohr's formula for the Rydberg constant. Thus most of the determinations of h/e by the $\mathrm{X}$-ray method have given values that are $0 \cdot 3-0 \cdot 4$ per cent lower than the value calculated. This difference is several times greater than the stated limits of error, indicating the presence of systematic errors in the measurements. An error of this nature, due to too high a pressure in the $\mathrm{X}$-ray tube, has previously been pointed out by $\mathrm{me}^{\mathrm{I}}$. This error can amount to $0 \cdot 1-0 \cdot 15$ per cent and is therefore too small to account for the whole of the discrepancy. Further, a number of determinations of $h / e$ have been carried out by means of technical X-ray tubes in which the pressure was sufficiently low.

In the determinations of $h / e$ carried out by $\mathrm{me}^{2}$, with the aid of a bent crystal and Geiger counter, a very narrow spectral band could be used on account of the greater intensity of the method, and the voltage was varied by very small steps (about 2 volts). Only the very lowest part of the isochromats, up to about 10 volts from the threshold voltage, was investigated. This part of the curves proved to be linear and gave a sharply defined determination of the threshold voltage. The value obtained, $h / e=(1 \cdot 3787 \pm 0 \cdot 0008) \times 10^{17}$ erg. sec./E.S.U. agrees within the limits of error with the calculated value. In a later paper ${ }^{3}$ I have described how I investigated the isochromats by the same method, up to 40 volts from the threshold voltage. The eurves proved to be linear up to 10 volts from the threshold, where a maximum was obtained. From 10 volts upwards the intensity sank, reaching a minimum at 20 volts and rising again thereafter, though less steeply than before. This indicates the occurrence of a systematic error, by extrapolating from the upper part of the curve.

I have now adopted a series of isochromats of the wave-lengths $2498 \cdot 42 \mathrm{X} . \mathrm{U}$. (vanadium $K \alpha_{1}$ ) and 